\title{
Study on the Electrodeposition of Chromium from Cr(III) Solution in the Presence of Oxalate and Acetate Anions
}

\author{
Dennys Fernández Conde*, German Orozco Gamboa, Julieta Torres González. \\ Centro de Investigación y Desarrollo Tecnológico en Electroquímica. \\ Parque Tecnológico Qro. Sanfandila, P.O. Box 76703, Pedro Escobedo, Querétaro, México. \\ "E-mail: dfernandez@ cideteq.mx
}

doi: $10.20964 / 2020.06 .70$

Received: 27 November 2019 / Accepted: 2 April 2020 / Published: 10 May 2020

\begin{abstract}
A Hull cell was used to evaluate a chromium(III) plating bath based on the combination of oxalate and acetate anions. The bath contains chromium(III) sulfate, ammonium oxalate, sodium acetate, boric acid, potassium sulfate, sodium sulfate and sodium dodecyl sulfate (SDS). The working $\mathrm{pH}$ was 3.5, and all species were protonated. The chromium(III) plating bath had a faradaic efficiency of $37 \%$, high covering power at $8.2 \mathrm{~cm}$, low deposition potential of $7.3 \mathrm{~V}$, and a deposition rate of $0.4 \mu \mathrm{m} / \mathrm{min}$. Chromium coatings were obtained at a current density $\left(30 \mathrm{~A} / \mathrm{dm}^{2}\right)$. This chromium(III) plating bath is competitive considering the state of the art of the electrodeposition of Cr(III). SDS was used as a surfactant to prevent the formation of polymeric oxides (olation reactions) by decreasing the number of nearby ions of $\mathrm{Cr}(\mathrm{III})$. Boric acid successfully maintained the $\mathrm{pH}$ as a buffer because after $2 \mathrm{~h}$ of the electrodeposition process, the $\mathrm{pH}$ values change only 0.2 units. The bath was analyzed after electrolysis to check the formation of $\mathrm{Cr}(\mathrm{VI})$ ions, and after $2 \mathrm{~h}$ of electrodeposition, this cation was not detected. The voltammetry results showed a very high noise with a potential of $-0.8 \mathrm{~V}$ due to the abundant bubbles that formed and suggest a reduction in a step from $\mathrm{Cr}(\mathrm{III})$ to $\mathrm{Cr}(0)$. In the literature, the use of oxalate anions is explained by the reaction of exchange of ligands between these anions and the water of the first solvation sphere of $\mathrm{Cr}$ (III). In our study, it is postulated that electrostatic interactions of ion-ions and ion-solvents should be very present, and that oxalate and acetate anions are very likely to be in the second sphere of solvation and not in the first as other authors propose. The water molecules in the first solvation sphere are very stable and difficult to replace because they are exposed to two opposite electrostatic forces at their ends.
\end{abstract}

Keywords: chromium(III) plating bath, solvation sphere, ligands, chromium electrodeposits, hull cell.

\section{$\underline{\text { FULL TEXT }}$}

(C) 2020 The Authors. Published by ESG (www.electrochemsci.org). This article is an open access article distributed under the terms and conditions of the Creative Commons Attribution license (http://creativecommons.org/licenses/by/4.0/). 